University of New Hampshire

University of New Hampshire Scholars' Repository

$5-8-2015$

\title{
Developing Critical Social Justice Literacy in an Online Seminar
}

\author{
Elizabeth Bondy \\ University of Florida \\ Elyse Hambacher \\ University of New Hampshire, elyse.hambacher@unh.edu
}

Amy S. Murphy

University of Florida

Rachel Wolkenhauer

Pennsylvania State University

Desirae Eva Krell

University of Florida

Follow this and additional works at: https://scholars.unh.edu/educ_facpub

Part of the Education Commons

\section{Comments}

This is an Author's Original Manuscript of an article published by Taylor \& Francis in Equity and Excellence in

Education on 08 May 2015, available online: http://dx.doi.org/10.1080/10665684.2015.1025652

\section{Recommended Citation}

Bondy, E., Hambacher, E., Murphy, A., Wolkenhauer, R., \& Krell, D. (2015). Developing critical social justice literacy in an online seminar. Equity and Excellence in Education, 48(2), 227-248.

This Article is brought to you for free and open access by the Education at University of New Hampshire Scholars' Repository. It has been accepted for inclusion in Education Scholarship by an authorized administrator of University of New Hampshire Scholars' Repository. For more information, please contact Scholarly.Communication@unh.edu. 


\section{Developing Critical Social Justice Literacy in an Online Seminar}

Education at its best is an enterprise geared to helping every human being reach the full measure of his or her humanity, inviting people on a journey to become more thoughtful and more capable, more powerful and courageous, more exquisitely human in their projects and their pursuits (Ayers, Quinn, \& Stovall, 2009, p. 725).

With these words the editors of the Handbook of Social Justice in Education share a vision of education in a democracy. In fact, they assert, education for social justice is "the rock upon which we build democracy" (p. xiv), and they describe its three pillars: equity of educational access and outcomes; agency to change unjust conditions; and social literacy, or the ability to "read the world" (Freire \& Macedo, 1987) and understand the connections between macro layers of context (i.e., history, politics, economics, culture) and micro experiences within schools, classrooms, and everyday life. The purpose of this paper is to report on an effort to cultivate what Sensoy and DiAngelo (2012) call a "critical" social justice perspective and critical social justice praxis among educators enrolled in an online graduate program.

The cohort of 19 educators live the reality of schools across the U.S. They observe opportunity and outcome gaps between their White students and their students of color; they notice their Black male students leaving high school without graduating; they witness and sometimes practice the harsh and relentless disciplining of students of color; they see increasing poverty and evidence of poor health care and nutrition among families in their school communities; and they detect increasing numbers of students and families whose language and cultural wealth are not in sync with those valued in their districts. Furthermore, these educators receive countless directives to address these disturbing trends with new programs, policies, and practices. In short, the members of the cohort are embedded in $21^{\text {st }}$ century public schooling in the U.S. 
Although the entire graduate program was organized around themes of equity, collaboration, and leadership, the Critical Pedagogy course served as the students' formal introduction to the meanings and practices of social justice education. Interested in their perspectives on the purposes, pedagogy, and outcomes of the course, we asked three questions: (1) What purposes did the course serve for the educators? (2) How did the course affect the educators' perspectives and practices? (3) What course features did the educators perceive shaped their perspectives and practices? Following a review of the theoretical framework that guided our work, we clarify the context of the study and the methodology used to examine the research questions.

\section{Theoretical Framework}

The purpose of the Critical Pedagogy course was to stimulate the conscientization process of reading the world which entails achieving a "deepening awareness of the social realities which shape [our] lives" (Darder, Baltodano, \& Torres, 2009, p. 14) and a commitment to taking action to improve the lives of all human beings. Sensoy and DiAngelo (2012) refer to this as a process of developing one's "critical social justice literacy" (p. xix). They attach the term "critical" to the common phrase "social justice" in order to highlight their assumption that society is indeed divided and unequal "in significant and far-reaching ways along social group lines that include, race, class, gender, sexuality, and ability" (p. xviii). A critical theoretical perspective is needed to recognize the ways in which injustice is deeply embedded in the fabric of our lives and shapes the lives of children and adults in and out of school. In order to engage in critical social justice praxis, one must be willing to examine one's own socialization and positionality within societal relations of unequal power (Hackman, 2005). Critical social justice 
literacy refers to the blend of critical, personal, and sociological analysis and action to achieve a more socially just society.

To accomplish these goals in an online course with full-time educators, course content and pedagogy were situated within the framework of Mezirow's (2000) theory of adult transformative learning as it has been enhanced by the work of other scholars and practitioners of transformative learning (e.g., Fisher-Yoshida, Geller, \& Schapiro, 2009) and by Bakhtin's (1981) discussion of "ideological becoming," the process by which people develop a worldview or ideological self. Mezirow (2000) asserts that transformative learning takes place through a process of critical reflection facilitated by open dialogue in a safe setting. This process is not necessarily rational; in fact, the whole person (not solely one's "logic") is often engaged in the learning process, and as such, "extrarational body, spirit, and emotion/feeling” can play as prominent a role as the rational and cognitive (Fisher-Yoshida et al., 2009, p. 290).

According to Bakhtin (1981), however, the social interactions that are most effective in promoting learning are those that embody conflict. As Geller (2009) summarized, practitioners and scholars who work from a transformative learning perspective agree, and use various terms to refer to this conflict (e.g., disorienting dilemma, trigger event, disconfirmation, confusion and withdrawal). Harro (2013) viewed the conflict as a necessary first step on the path to critical transformation and referred to the step as "waking up." She explained that waking up is characterized by "cognitive dissonance, where something that used to make sense to us (or that we never questioned), ceases to make sense" (p. 465). This struggle, while integral to learning, is more likely to be successful within a space that is characterized as open and emotionally safe, as Mezirow suggested. In short, as Ball and Freedman (2004) have written, "In a Bakhtinian sense, 
with whom, in what ways, and in what contexts we interact will determine what we stand to learn" (p. 9).

We were also informed by Schapiro's summary of the characteristics of transformative learning spaces such as:

learning happens (1) in relationships, (2) in which there is shared ownership and control of the learning space, (3) room for the whole person-feelings as well as thoughts, body and soul, as well as mind, (4) and sufficient time for collaboration, action, reflection, and integration, (5) to pursue a process of inquiry driven by the questions, needs, and purposes of the learners. (in Fisher-Yoshida et al., 2009, pp. 111-112)

Although the course instructor had some experience creating these conditions in a face-toface seminar (Authors, 2012), she was not an experienced online teacher and wondered if she could cultivate the climate and create the structures for potentially transformative learning in the virtual classroom. Although we found no literature on conducting an online critical pedagogy course, the growing scholarship on online teaching of adults indicated that it was indeed possible. For example, Dede (2006) published a synthesis of expert knowledge of online professional development in which he highlighted features of the online environment that have the potential to support transformative learning; for instance, the asynchronous component of online environments tends to provide more time for reflection, and the social "distance" can facilitate the introduction of risky topics that participants might be hesitant to broach face-toface. A growing body of research on online adult learning communities recommends ways to facilitate learning as a social constructivist process (Snyder, 2009). In fact, drawing on research in the field of learning communities, adult learning theory, and constructivism, Snyder proposed an instructional design theory to "foster the sharing of information, knowledge, skills, and 
experiences among adults with common interests and goals, through online communication, collaboration and interaction" (p. 50). The theory delineates values, methods, and situations in which the methods may work best. However, Snyder suggests there are multiple questions about the model and its impact.

The development of critical social justice literacy appears to require a learning environment that can sustain collective and individual struggle with the disorienting dilemmas and confusion that are expected when people attempt to read the world and their position in it. In this study, we were eager to gain insight into the educators' experience of grappling with the fundamental concepts of critical social justice in an online environment.

\section{Context}

The context of this study is an online graduate program designed for full-time educators. The purpose of the program is to serve practicing education professionals who wish to lead educational change and improvement from inside the system and/or take on other leadership roles that will impact the world of practice. In other words, the program seeks to help educators become practitioner scholars who

bring theoretical, pedagogical, and research expertise to bear on identifying, naming, and studying problems of practice and leading informed change in their schools and districts to continually improve learning conditions for students and adults who work within their local contexts. (Authors, 2010, p. 3)

The design of the program draws heavily upon the literature on teacher leadership and professional development. Four principles in particular are influential: coursework is jobembedded (York-Barr \& Duke, 2004), leadership is a practice and not a position (Feeney, 2009), inquiry and reflection are a pervasive focus (Feeney, 2009; Harris \& Mujis, 2003; York-Barr \& 
Duke, 2004), and collaboration is stressed throughout the program (Edge \& Mylopoulos, 2008; Feeney, 2009). The program's focus on problems of practice in local settings and job-embedded coursework create a ripe context to help practitioners understand and work to address systemic biases, financial inequalities, and entrenched hierarchies that cause deep divisions among diverse learners in educational achievement, preparation, and power (Darling-Hammond, 2010; LadsonBillings, 2006; Noguera, 2010).

The 19-student cohort participated in the Critical Pedagogy course for 14 weeks during the fall of 2011, their fifth semester in the program. The course was designed to destabilize educators' tacit assumptions about themselves and their positions in society as well as the structures and processes of schooling. As such, it aimed to be transformative as well as informative and to engage educators personally as well as professionally in developing a critical social justice perspective. Course readings included work from scholars such as Peggy McIntosh (1989, 2009a, 2009b), Zeus Leonardo (2004), Kevin Kumashiro (2009), and Mary Cowhey (2006), and the course featured a deliberate blend of theory and practice in readings, discussions, and assignments. Because the educators spoke extensively of the content and structure of the course in the focus groups, we provide more information about the course in the Findings section.

\section{Data Collection}

The study was designed to understand (1) the purposes the course served for the educators, (2) how the course affected the educators' perspectives and practices, and (3) the course features that shaped their perspectives and practices. Online focus group interviews were the main source of data. Focus groups allowed us to access "group interaction[s] to produce data and insights that would be less accessible without the interaction found in a group" (Morgan, 
1997, p. 2). This approach was well suited for the educators who had completed five semesters

of interactive, online coursework within the same cohort. Consequently, they were familiar with one another and with interactions at a distance. Educators in the course were reminded that their participation was voluntary and, of the 19 educators, 14 chose to participate in one of the six focus groups. Demographic data about the 14 participants are summarized in Table 1 , and the protocol that guided the semi-structured focus groups may be found in Appendix A. The research team consisted of the faculty member who taught the online Critical Pedagogy course and four doctoral students who helped to design the course. All focus group interviews took place after the completion of the course and were conducted by the doctoral students. Participants were assigned pseudonyms to be used in all references to the data, including the transcripts. All interviews were audio recorded and transcribed verbatim.

\section{Data Analysis}

All researchers analyzed the interview data using an interpretive approach that drew from constructionist grounded theory methodology. Charmaz (2006) explained that this approach "places priority on the phenomena of study and sees both data and analysis as created from shared experiences and relationships with participants" (p. 130); as such, this methodology aligns well with our questions about the educators' shared experiences and knowledge construction within the course and the focus groups.

The team engaged in an explicit, analytic process in accordance with constructionist grounded theory (Charmaz, 2006). First, we reviewed the data set as a whole and met to discuss initial impressions. Transcripts were then divided among the researchers. We developed initial codes of meaning units using gerunds and participants' own words whenever possible. Codes were simple and precise which helped us to refrain from imposing personal motives or agendas 
on the data. Second, we met again to develop focused codes, which allowed us to consolidate initial codes to form broader conceptual clusters. As an example, "focusing on thinking," "pushing to be precise," and "being a sounding board" were consolidated into the larger focused code, "feedback from instructor," because our participants used these words to describe the type of feedback they received from the instructor during the course. Figure 1 is an example of common initial codes and their relationship to focused codes and broader clusters. As a next step, we began memo writing, which prompted us to define the properties and characteristics of each cluster for further analysis (Charmaz, 2006). Memo writing helped us to discuss relationships among focused codes and refine our understanding of participants' experience.

Throughout the analysis, peer debriefing helped us develop the codes formed at each stage of the process. Through an iterative and recursive process with all members of the research team, we sought confirming and disconfirming evidence of themes in the data. This helped us to finalize the major findings that emerged related to the educators' experiences in the online course.

\section{Findings}

The participants entered the course with a variety of experiences and dispositions that informed how they responded to the concepts and materials. This section begins with an examination of the ways in which the course served different purposes for educators. Next, we look at how the course affected educators' emerging critical perspectives and their school-based practices. Finally, we discuss the course features that the educators perceived to shape their perspectives and practices. 


\section{Student Responses to the Course}

Because of the personal dissonance stimulated by the course material, most educators echoed Matt's assertion that "all of us basically got our own personal course out of this" (Focus group interview, December 13, 2011). Nevertheless, we found that the educators' experiences in the course could be organized into three categories. For two educators, the course intensified their previously held critical perspectives. Most educators had a transforming experience, as the course disrupted their common sense understandings and launched a process of critical reflection. For one student in particular, the online course was simply informative; while he claimed to have gained knowledge, he asserted that his worldview was not apt to change. We present these responses in discrete categories. However, most of the educators described their experiences as fluid, and it was particularly challenging to draw a firm line in some cases between intensified and transforming experiences, as some educators provided evidence of both. As such, we describe them as a continuum of responses ranging from those that were simply informed to those that deepened previous beliefs about and commitments to social justice.

Intensifying experience. Though Lydia and Susan did not have the language of critical pedagogy at the outset of the course, they brought with them a critical perspective. The readings, discussions, and assignments created an "intensifying" experience for these educators by helping to bring into sharper focus critical understandings they already held.

For Lydia, a district coordinator for Title I schools, this sharpening occurred through the power of naming. That is, the course equipped her with the lexicon and a framework to describe social phenomena she had already observed in her life yet did not have the linguistic tools to name. In describing her experience of learning about the word "hegemony" she said, "Once I was able to name it, it's almost like I was able to take more authority. I began to be able to see 
aspects of hegemony, whereas before it was just big and amorphous and overwhelming" (Focus group interview, December 15, 2011). Developing the lexicon of critical pedagogy empowered her to "pull at hegemony ... and get a better handle on it" (Focus group interview, December 15, 2011) as she observed it in action.

Similarly, the class provided an opportunity for Susan, an ESOL coach, to explore and articulate an already budding critical perspective. She explained, "No class has stirred passion in me the way this class has...I've always questioned and wondered why things are the way they are. This gave me the format to really dig deeply and have conversations that are hard to have" (Focus group interview, December 13, 2011). The opportunity to explore her long-held wonderings with other educators helped to intensify her understandings about power and privilege in society and schools.

The course helped both Lydia and Susan realize that their ways of experiencing the world--including interacting with their students, colleagues, and supervisors - were grounded in a social justice stance. Susan explained, "[the] course really pushed me personally to turn inward" to examine her previously held positions (Focus group interview, December 13, 2011). Her deep reflections led her "to want to fight if you will...for values and beliefs that I've sort of always had but maybe didn't realize how surface they were in the past" (Focus group interview, December 13, 2011). Ultimately, both of these educators' critical perspectives intensified as they learned the names for phenomena they had long known implicitly and came to recognize themselves as agents of social change.

Transforming experience. We describe the majority of the participants as beginning to experience the process of conscientization. Showing evidence of a shift toward a critical perspective, we refer to these educators' experiences as "transforming." 
The first step for some of the educators was to embrace a "willingness to be disturbed" (Wheatley, 2002, p. 34) by stepping out of their comfort zones in the pursuit of professional and personal growth. Rather than solely looking outward for evidence of inequity, these participants pursued deep self-reflection about the ways they interact with others. As an elementary school principal, Teresa recognized that she did not personally engage in the level of critical reflection she expected from her own teachers:

I was actually pushing my teachers to do this, but I don't know if I was doing it as much myself with looking at stereotypes and bias and prejudices. What is our thinking? What do we want to reduce, and what's our action plan to reduce that? You know, I was really pushing my teachers to do that but I don't know if I was pushing myself enough (Focus group interview, December 15, 2011).

The course, coupled with an honest self-assessment, led Teresa to "push myself to think more deeply about my own opinion, my own position, and my own action" (Focus group interview, December 15, 2011).

Some participants described the course as having transformed the way they see the world. Six educators described the course as providing them a new "lens," and two others described the course as “an eye-opener.” In Hope's words, "It was ... a new lens on what we already do and how to improve it, how to push yourself to improve it" (Focus group interview, December 13, 2011). For these educators, the course taught them to see covert power structures in society and schools. Natasha explained, "[The course] was very thought provoking and opened up my world to recognize the oppression and the racism and...the common sense things that we take for granted" (Focus group interview, December 15, 2011). This awareness that they had previously 
taken power and privilege for granted led some participants to challenge their tacit assumptions about the world.

Kim, who works in the district's professional development office, described how each of the readings led to a series of critical self-reflective questions: "How would I do this? How would I deal with students this way? What are my assumptions around this? Everything challenged my thinking about who is saying this, who is preaching this, who is doing this?" (Focus group interview, December 12, 2011). Other participants described this newfound questioning as a response to everyday encounters in their lives. For example, Karen wondered about others' intentions and actions in her role as a reading coach. Natasha also explained that the course "develops your awareness of the world and practices around you. It has you question who you are as a person and the things that you believe or take for granted or consider common sense" (Focus group interview, December 15, 2011).

While most of the participants who we describe as "transforming" talked about their response to the course with enthusiasm and openness, this was not the case for all. Matt's experience was marked initially by hesitation: "It was a little much for me because they were ideas that I didn't necessarily fall in love with right away" (Focus group interview, December 13, 2011). He further explained how the process of writing about his ideas in the course assignments led him to recognize his own transformation:

It was strange for me because when I wrote the first paper I noticed it's like your thinking is actually changing on this-like I could tell that I was changing even as I was writing it. And I think that was really good for me to be able to put myself in other positions and see things from other perspectives. Even if those perspectives don't become my worldview, 
it's something that I can certainly use to influence...education. (Focus group interview, December 13, 2011)

Despite his initial hesitation, Matt's participation in the discussions and assignments opened him up to the possibility of a transforming experience.

Informing experience. One student obediently participated in the course, but made it clear that his well-formulated worldview was not likely to shift. We describe him as being "informed" by the course, as there was no evidence of change in his way of seeing the world.

Scott, an assistant principal, explained that while the course gave him "food for thought," he did not "know if it's added to my work as a practitioner scholar" (Focus group interview, December 12, 2011). He further explained that how one approached the course depended upon the worldview with which one entered: "I know things and how I see the world and how I interpret the events that occur in the world. That is pretty well set. That's not something that I'm going to be apt to change" (Focus group interview, December 12, 2011). Further, his disagreement with the course content reinforced his stance. He explained, "I didn't agree with all the assertions... [and the] conclusions that were drawn from those assertions. So it was just reading somebody else's viewpoint. It's interesting to see the viewpoint, but I didn't necessarily agree with it" (Focus group interview, December 12, 2011). Thus, while Scott found some of the material informative, his unyielding worldview limited his responsiveness to the course.

We recognize it is possible that others may have had experiences similar to Scott's, though we could not identify them in the data from the other 13 participants. The majority of the educators shared that their experiences in the course transformed their thinking about society, education, and their own lives. Although our knowledge of the participants and the data suggest 
otherwise, it is possible that some of the educators were telling us what they thought we wanted to hear.

\section{Evidence of Learning in Practice}

The continuum of responses gives us a sense of the broad ways in which educators experienced the course. Next, we examine educators' emerging critical perspectives and schoolbased practices related to the course. What insights did educators gain? What did they appear to learn? Most importantly, what did the participants do with their new understandings?

Recognizing blind spots. Many of the educators experienced the cognitive dissonance fundamental for transformative learning (Mezirow, 2000), noting “ah-ha" moments of recognition at their new ways of seeing the world. Lydia described this cognitive dissonance as a "chasm" as she began to question the relationship between her previous assumptions about herself and her actions. She revealed, "It made me see this gap between who I am in my ideal mind and who I am in practice" (Focus group interview, December 15, 2011). Karen's statement, "It's almost like I'm not as blinded as I used to be in my thinking" (Focus group interview, December 13, 2011), resonates with several educators' responses about how the course affected their professional and personal lives.

For the predominantly White, female, and heterosexual group of educators, blind spots emerged as they developed an awareness of White privilege, male privilege, and straight privilege. Several White educators discussed how they had never considered the concept of White privilege prior to the course and how it opened their eyes to advantages they never realized they had. For Maria, a district administrator, McIntosh's articles (1989, 2009a, 2009b) on White privilege were "complete enlightenment. [They] opened my eyes, my mind, my heart." Further, as a Black woman dating a White man, Natasha explained that the readings on White 
privilege and women's oppression (Frye, 1983) “opened up a whole lot of different things that I probably never chose to take a look at [before]" (Focus group interview, December 12, 2011).

Others spoke about their new awareness of straight privilege. As an elementary teacher, Jeff had never considered how issues of sexual orientation might affect his students until reading about a gay man's experiences in school and learning about suicide rates among gay youth. Jeff explained that this reading impacted him deeply: "It hit me, and it hit me at my core just because I honestly hadn't even considered it, and so I just felt like it was something I shouldn't have overlooked, but I've been overlooking it" (Focus group interview, December 12, 2011). Maria also commented on her recent shock when learning that a former student was gay. She said, "I didn't see it. I ignored it" (Focus group interview, December 12, 2011) and now laments her blindness towards this important part of the student's life.

By virtue of being White, male, or straight, some educators grappled with the recognition that they benefited from a system that oppressed others. This chafed against some of their notions of what it means to be a fair and equitable person as they began to recognize the inadequacy of good intentions. Anna boldly asserted her new awareness that "Being nice and being a good person doesn't necessarily mean that you are not an oppressor" (Focus group interview, December 13, 2011). Others shared Jeff"s sentiment that "this course has helped me to realize and recognize the difference between my intentions versus my actions" (Focus group interview, December 12, 2011).

Participants also shared that the course taught them to recognize the systemic nature of power and inequity in the U.S. education system. For example, as a reading coach who participates in school and district-level meetings, Karen started to question, "With any decisions that are made at the school or the county or whatever level, I'm stopping and I'm considering, 
what are the systems in play? What are the assumptions people are making?" (Focus group interview, December 13, 2011). While she was unsure of how her "pausing and analyzing" would impact her work as a practitioner, Karen believed she had become more invested in understanding who is advantaged and disadvantaged by the structures and practices of schools. Like Karen, several of the participants were not yet ready to act on their new awareness of the power structures at play in schools and society. Nevertheless, they recognized several blind spots that hindered their ability to read the world.

Conceptualizing critical action. In addition to recognizing their own blind spots, some educators began to think about and share internal deliberations about taking critical action. For example, Anna discussed course assignments that required her to apply critical pedagogy concepts to her work, thus helping her engage in critical action: "[The assignments] just helped me see, 'Oh, I can do this. I can address this in my little world.' It was doable—it wasn't just this big esoteric kind of conversation about huge global issues that I can't do anything about" (Focus group interview, December 13, 2011). Anna began to consider how she could use her leadership position as an assistant principal to enact changes in her school.

Similarly, Maria shared that throughout the PPD program, she struggled with the notion that social change could happen in schools. During the course, she came to the conclusion that schools must be a part of social change and that educators should not wait until children become adults to teach for social justice. As she considered how this would impact her work she shared, "You have to go to the edges because there are people on the edges, and there are practices on the edges, and that's not ok" (Focus group interview, December 12, 2011).

Nearly all educators discussed how the course impacted their personal lives. In particular, those with children began to consider how they could impact the ways their children understand 
and interact with the world. As the father of a young girl, Jeff wondered how he could help to prepare her for a misogynistic world. Similarly, the readings spurred Alice to discuss with her husband how they would raise their son "so that we're not being a contributor to some of the oppression that takes place" (Focus group interview, December 13, 2011). Although these educators had not identified specific actions they might take in their parenting, they had certainly begun to consider how they could be agents of social change in their personal lives.

Implementing critical action. Many educators talked about critical action they had already undertaken during the semester they took the course. These participants were engaged in “praxis," or action informed by critical sociological analysis (Freire, 1993).

For some educators, this meant using their voices as a tool of social justice by asking uncomfortable questions and speaking up in their work with other educators. As a district director of Title I schools, Lydia often found herself in situations in which she felt obligated to speak up. She revealed the fear that accompanied such boldness:

I think sometimes my role is to just keep the heat...Because I realized that sometimes I just didn't speak up, I didn't say anything...I was not heat and light. I just kind of turned my head the other way. So as a practitioner I don't do that anymore, and so now it's, 'Am I going to get kicked out? Am I going to be in trouble? Am I going to not be invited to the party anymore?' I don't know. (Focus group interview, December 15, 2011).

Lydia felt a moral imperative to address inequitable practices head on, despite possible ramifications of using her voice so boldly. She also changed her leadership team's structure to include voices of support staff, who she previously excluded, to ensure representation from all levels of staff as they strategize, plan, and envision their work. 
In another example, Anna, an assistant principal, encouraged her teachers to recognize how their words and actions position students and families. She explained that the course gave her new ways of responding to teachers who complain to her about students or their parents:

It has helped me to take the teachers away from blaming everything else and to look more at themselves and what can they do differently in the classroom...I'm trying to help teachers really think about their practice before they think about assumptions of what's going on based on the families or the kids. (Focus group interview, December 13, 2011).

Prior to the course she had never considered these issues, but she now consciously approaches her work with teachers from a more critical perspective.

Hope, a pre-K teacher, also made tangible changes in her work with parents as a result of the course. She used her new knowledge of cultural capital to make her communications with parents more welcoming and accessible. She also invited parents to attend social events to break down barriers between school and families.

\section{Course Features}

As we learned about the educators' emerging critical perspectives and school-based practices, we also learned that the Critical Pedagogy course stimulated new insights, introduced new strategies, and at times, fostered critical action in practice. The educators reported several course features that they believed contributed to their learning and practice. In the next section, we discuss the unique features of the online job-embedded course.

Course placement. Educators took the Critical Pedagogy course in the fifth semester of their program. This placement contributed to the changes we saw in educators' growth and development. Prior to studying social justice issues in depth in this course, the cohort had received a foundation of theory, research methods, and overall program goals that introduced 
them to the necessity for a critical pedagogy course. For example, the semester immediately preceding Critical Pedagogy included a history of education course that discussed the evolution of present-day school structures and processes as well as the diverse schooling experiences of sub-groups of the U.S. population. Thus, when educators began the course, they had the skills and mindset necessary to deeply and critically study otherwise conceptually and emotionally difficult content.

Additionally, at this point in the program, they had built collegial relationships with the other educators and with university faculty. This prior rapport building established mutual respect and trust among classmates and the course instructor, allowing the class to begin the often intense conversations around social justice issues from the very beginning of the course. Karen explained, "I think we had to build to this point to be that comfortable and vulnerable...this course is ideally situated in a cohort kind of environment" (Focus group interview, December 13, 2011). These conversations could occur earlier and at a deeper level than is typical for face-to-face classes.

Online facilitation. Another reason critical conversations were able to occur was that most of these conversations happened online. Online facilitation is another unique feature that contributed to the experience for educators. Since the majority of the course was facilitated through an online course management tool, educators reported feeling more comfortable to take risks. Asynchronous communication allowed educators more time to be reflective, craft their comments carefully, and edit posts if they had new or different ideas at later times. Karen reflected on the importance of this when she said, "The nature and the sensitivity of the topics [in this course] made it that you had to be very reflective and really monitor what you were saying and how you were saying it" (Focus group interview, December 13, 2011). Educators also 
reported that, unlike traditional face-to-face classes, they weren't afraid of being interrupted and, therefore, misinterpreted, when they communicated online. They had the freedom to compose responses to one another that were at the same time personal and scholarly, contributing to the rich dialogue, experiences, and dispositions that we saw come out of the course.

Face-to-face facilitation complemented online facilitation. While educators found great value in taking the course online, they described the importance of the face-to-face component built into the program. Educators gathered in person for a one-day, mid-course meeting that provided the chance to dive into some particularly challenging materials for further discussion. For instance, Anna described the face-to-face meeting as "a key element of this particular course because it is such deep rooted content and [taken] out of context can be so scary" (Focus group interview, December 13, 2011). By having face-to-face dialogue, educators had the opportunity to have synchronous conversations that were co-created and spontaneous, as opposed to the more individualized, composed conversations they had online. They appreciated the opportunity to observe the non-verbal communication of their peers as well as the opportunity to get immediate assistance in interpreting what they viewed as particularly challenging readings by Leonardo (2004) and Frye (1983). By meeting in the middle of the semester, educators reported feeling more connected to their classmates, ensuring that the online conversations did not begin to feel disingenuous during the second half of the course.

Scaffolded content. The structure of content in the course also contributed to how educators experienced the course and developed as practitioners. The readings, for example, were carefully organized to ensure student learning was scaffolded while content was strategically revealed. The prudently designed sequence started and ended with readings focused on practice (Cowhey, 2006; Fehr \& Fehr, 2010) with theoretical readings in the middle (Frye, 
1983; Hinchey, 2010; Leonardo, 2004; McIntosh, 1989, 2009a, 2009b) that built upon and served as a foundation for practice. This sequence highlighted for educators the immediate relevance for critical pedagogy and helped them delve into the theoretical underpinnings of critical pedagogy to be more informed, ultimately applying this new depth of knowledge back into their practice.

In addition to a carefully planned reading sequence, the course designers used an online structure familiar to the educators. By coming into a familiar course structure, they were able to focus on the content as opposed to navigating a new online course management system. The course structure was the same used in one of the first-semester classes that educators reported liking because it was easy to navigate and kept them focused on the course throughout the week. The first ten weeks of the class followed the same format. Each week began with an introductory statement from the course instructor. Educators then participated in a whole group pre-reading "Thought Question" discussion before engaging with the "Content of the Week." After reading the week's content, educators responded to post-reading "Discussion Question(s)" within small groups. Finally, they took their learning from the week back into their work through “Application Assignments," which included weekly journals as well as course assignments in which educators reflected on or applied critical pedagogy concepts.

In the final four weeks of the course, structured similarly to an independent study, educators took what they had learned back to their workplaces. Each student enacted a strategy applying critical pedagogy and then wrote about the experience, connecting to course readings. During the last week, educators composed reflective letters to represent their current understandings and practices of critical pedagogy in response to preliminary letters written at the beginning of the semester. 
The educators we interviewed talked extensively about the effectiveness of course scaffolding. Jeff, for example, reflected:

We were able to connect [the content] to our context. What I really appreciated about this course was it caused me to be really introspective and think about myself as an individual within the system. I felt the focus was more like examining your own beliefs and how those beliefs then fit in the larger system. It [made for] a very personal, reflective type of experience. (Focus group interview, December 12, 2011).

Feedback. The way feedback was provided made a unique contribution to educators' experiences and developing dispositions. The course instructor provided two kinds of feedback: synthesized reflections at the end of each week based on whole and small group discussions and individual, personal feedback to weekly journals and major assignments. Weekly syntheses were carefully crafted to push educators' thinking, support their growing understandings, and acknowledge specific student contributions within the whole class context. Individual feedback focused on content rather than mechanics, effectively helping educators to tease out complex ideas while pushing them to more deeply understand new concepts. The educators reported that the focus of individual feedback was unique to this course. Both forms of feedback helped educators understand the goals of the course. Teresa commented on the feedback's focus by stating that it "was less [about] referencing the thinking of others and far more [about a] push to formulate our own thinking” (Focus group interview, December 15, 2011).

\section{Implications}

The experiences of the educators in the online Critical Pedagogy course have implications for teacher educators who wish to promote critical social justice literacy. In particular, this study provides insight into features of online pedagogy that appear to facilitate 
transformative learning. In fact, many of the educators' insights about important course features are consistent with the methods Snyder (2009) included in her instructional-design theory for the creation of online, adult learning communities, which recommends that an instructor should

- demonstrate how the purpose of the course relates to the students' world;

- $\quad$ establish trust and support among students and with instructor;

- facilitate interaction, collaboration, and reflection;

- encourage sharing of information, knowledge, and experiences;

- reinforce, recognize, and reward students' efforts;

- focus on real-life problems;

- provide assignments that learners can apply to their unique situations;

- maintain a consistent and predictable learning environment;

- $\quad$ provide consistent, formative feedback to students throughout the semester;

- $\quad$ expect students to examine what they have learned over the semester. (Snyder, 2009)

Less apparent in Snyder's framework yet important to the development of critical social justice literacy is the content used to stimulate discussion. For the educators in this study, the balance of practice- and theory-oriented readings was vital. The content was deliberately sequenced so as to move educators gradually into grappling with the dissonance required when learning to read the world while maintaining contact with the particulars of the settings in which they worked. Keeping social justice relevant to the real world and easing educators into the discomfort that comes when dissonance is introduced were perceived as important features of the course content.

Another insight not found in Snyder's online framework was the educators' appreciation for an opportunity to meet face-to-face midway through the semester. This meeting was possible 
because all of the educators lived in one state and could gather at a midway point; we recognize that all educators may not have the luxury that our geography afforded us. The personal contact during this meeting was particularly important given the nature of class discussions. When power, oppression, and the risky topics of race, social class, gender, and sexual orientation are on the table, participants can be anxious about how their comments are perceived. The face-to-face meeting provided a personal "checking in" that appeared to facilitate and support honest online communication. It is worth considering the periodic use of technologies that approach face-toface communication when course content stimulates dissonance and discomfort among educators.

Finally, the educators pointed to the professional and personal dimensions of the course content. The emotions they displayed and their references to how the content touched their personal lives revealed that the course was not solely an academic exercise. Although educators were learning knowledge, skills, and dispositions that affected their professional practice, they were also developing a critical lens that helped them to see themselves and their lives in new ways. Perhaps the depth of their personal engagement with the course had a bearing on the professional knowledge they gleaned from it. Similarly, emotions played a more prominent role in the course than they typically do in higher education coursework. Though not surprising given the educators' personal engagement, it represents a departure from the intellectual focus of university courses. Schapiro's assertion (in Fisher-Yoshida et al., 2009) that environments that support transformative learning must provide "room for the whole person-feelings as well as thoughts, body and soul, as well as mind" (p. 111) strikes us as a principle to remember when developing online courses with a critical social justice orientation. 


\section{Conclusion}

Inequities in educational opportunities and outcomes have long been documented in spite of the flood of reforms that continue to wash over U.S. schools. Cultivating a critical stance among educators may be a means by which they can visualize what Freire (1993) called the "untested feasibilities" (p. 102)—possibilities yet to be considered that may produce

transformative change in schools and, more importantly, in the lives of children and families who have been inadequately served by our public education system.

The educators' experience in the Critical Pedagogy course provides teacher educators with some insights into how transformative learning might be accomplished. This kind of extended, scaffolded experience of unlearning and relearning may provide the foundation needed for educators to participate in the larger change efforts that are called for in schools (Carlisle, Jackson, \& George, 2007). Certainly, one course is insufficient to transform the common sense notions of schooling that have shaped the practice of educators. However, the findings suggest that not only can this work be accomplished in the online environment, but that there are features of online pedagogy that facilitate the kind of dialogue required for transformative learning.

Online environments may provide fertile conditions in which to help educators to read the world and act upon it in ways that create equity of opportunity and outcome for persistently marginalized students. 


\section{References}

Authors, 2010.

Authors, 2012.

Ayres, B., Quinn, T., \& Stovall, D. (2008). The handbook of social justice in education. New York: Routledge.

Bakhtin, M. M. (1981). The dialogic imagination (C. Emerson \& M. Holquist, Trans.). Austin: University of Texas Press.

Ball, A. F., \& Freedman, S. W. (2004). Ideological becoming: Bakhtinian concepts to guide the study of language, literacy, and learning. In A.F. Ball \& S.W. Freedman (Eds.), Bakhtinian perspectives on language, literacy, and learning (pp. 3-33). Cambridge, England: Cambridge University Press.

Carlisle, L.R., Jackson, B.W., \& George, A. (2007). Principles of social justice education: The social justice education in schools project. Equity and Excellence in Education, 39 (1), $55-64$.

Charmaz, K. (2006). Constructing grounded theory: A practical guide through qualitative analysis. Thousand Oaks, CA: Sage.

Cowhey, M. (2006). Black ants and Buddhists: Thinking critically and teaching differently in the primary grades. Portland, ME: Stenhouse.

Darling-Hammond, L. (2010). The flat world and education: How America's commitment to equity will determine our future. New York, NY: Teachers College Press, Columbia University. 
Darder, A., Baltodano, M. P., \& Torres, R. D. (2009). Critical pedagogy: An introduction. In A. Darder, M. P. Baltodano, \& R. D. Torres (Eds.), The critical pedagogy reader (pp. 1-20). New York: Routledge.

Dede, C. (2006). Online professional development for teachers: Emerging models and methods. Cambridge, MA: Harvard Education Press.

Edge, K. \& Mylopoulos, M. (2008). Creating cross-school connections: LC networking in support of leadership and instructional development. School Leadership and Management, 28(2), 147-158.

Feeney, E. J. (2009). Taking a look at a school's leadership capacity: The role and function of high school department chairs. The Clearinghouse, 82(5), 212-217.

Fehr, M. C., \& Fehr, D. E. (2010). Teach boldly!: Letters to teachers about contemporary issues in education. New York: Peter Lang.

Fisher-Yoshida, B., Geller, K. D., \& Schapiro, S.A. (Eds.) (2009). Innovations in transformative learning. New York: Peter Lang.

Freire, P. (1993). Pedagogy of the oppressed. New York: Continuum.

Freire, P. \& Macedo, D. (1987). Literacy: Reading the word and the world. South Hadley, MA: Bergin \& Garvey.

Frye, M. (1983). Oppression. In The politics of reality: Essays in feminist theory (pp. 1-16). Freedom, CA: The Crossing Press.

Geller, K. D. (2009). Looking through the lens of culture, difference, and diversity. In B. FisherYoshida, K. D. Geller, \& S. A. Schapiro (Eds.), Innovations in transformative learning (pp. 201-204). New York: Peter Lang. 
Hackman, H. W. (2005). Five essential components for social justice education. Equity \& Excellence in Education, 38(2), 103-109.

Harris, A. \& Muijs, D. (2003). Teacher leadership: Principles and practice. Nottingham, United Kingdom: National College for School Leadership.

Harro, B. (2000). The cycle of liberation. In M. Adams, W. J. Blumenfeld, R. Castañeda, H. W. Hackman, M. L. Peters, \& X. Zuñiga (Eds.), Readings for diversity and social justice (pp. 463-469).

Hinchey, P. (2010). Finding freedom in the classroom (Revised Edition). New York: Peter Lang.

Kumashiro, K. (2009). Against common sense: Teaching and learning toward social justice. New York: Routledge.

Ladson-Billings, G. (2006). From the achievement gap to the education debt: Understanding achievement in US schools. Educational Researcher, 35(10), 3-12.

Leonardo, Z. (2004). The color of supremacy. Beyond the discourse of "white privilege." Educational Philosophy and Theory, 36, 139-152.

McIntosh, P. (1989, July/August). White privilege: Unpacking the invisible knapsack. Peace and Freedom, 10-12.

McIntosh, P. (2009a). White privilege: An account to spend. St. Paul: Saint Paul Foundation.

McIntosh, P. (2009b). White people facing race: Uncovering the myths that keep racism in place. St. Paul: Saint Paul Foundation.

Mezirow, J. (2000). Learning to think like an adult: Core concepts of transformation theory. In J. Mezirow \& Associates (Eds.), Learning as transformation (pp. 3-34). San Francisco: Jossey-Bass.

Morgan, D. L. (1997). Focus groups as qualitative research ( $2^{\text {nd }}$ ed.). Newbury Park, CA: Sage. 
Noguera, P. A. (2010, March 23). Closing the achievement gap: Racial inequity and the unfinished legacy of civil rights in America. Motion Magazine. Retrieved from http://www.inmotionmagazine.com/noguera.html.

Sensoy, O. \& DiAngelo, R. (2012). Is everyone really equal? New York: Teachers College Press.

Snyder, M. M. (2009). Instructional-design theory to guide the creation of online learning communities for adults. TechTrends, 53(1), 48-56.

York-Barr, J. \& Duke, K. (2004). What do we know about teacher leadership? Findings from two decades of scholarship. Review of Education Research, 74(3), 255-316.

Wheatley, M. (2002). Turning to one another: Simple conversations to restore hope to the future. San Francisco: Berrett-Koehler. 
Table 1. Participant demographic information

\begin{tabular}{|l|l|l|l|l|}
\hline Pseudonym & Gender & \multicolumn{1}{|c|}{ Race } & \multicolumn{1}{c|}{ Professional Position } & \multicolumn{1}{c|}{$\begin{array}{c}\text { Years of } \\
\text { Experience }\end{array}$} \\
\hline Lydia & Female & African American & Director, Title I Compliance & 10 \\
\hline Natasha & Female & African American & $\begin{array}{l}\text { Administrative Director, School } \\
\text { Transformation Office }\end{array}$ & 31 \\
\hline David & Male & Hispanic & Elementary Principal & 14 \\
\hline Jeff & Male & White & Elementary Teacher & 7 \\
\hline Maria & Female & Hispanic & Director, High School Education & 17 \\
\hline Kim & Female & White & Program Director-Leadership Institute & 17 \\
\hline Scott & Male & White & Assistant Middle School Principal & 27 \\
\hline Teresa & Female & White & Elementary Principal & 22 \\
\hline Hope & Female & Hispanic & Elementary Teacher & 8 \\
\hline Alice & Female & White & Elementary Teacher & 6 \\
\hline Susan & Female & White & ESOL Teacher & 15 \\
\hline Karen & Female & White & Reading Coach & 31 \\
\hline Matt & Male & White & $8^{\text {th }}$ Grade Science Teacher & 4 \\
\hline Anna & Female & White & Instructional Coach & 6 \\
\hline
\end{tabular}


Appendix A

1. In what ways was the Critical Pedagogy course the same as other courses in the graduate program? In what ways was the Critical Pedagogy course different from other courses in the graduate program?

2. Has the Critical Pedagogy course helped you develop as a practitioner scholar? If so, in what ways?

3. Did anything in the course challenge your willingness to be disturbed? If so, what? Why do you think this was challenging for you?

4. How did the online environment facilitate and/or impede your learning about critical pedagogy? In particular:

- What role did small group discussion of readings play?

- What role did the weekly application activities play?

- What role did the course announcements play in your learning?

- What role did individual feedback play in your learning?

- What role did the assignments play?

5. You read the following texts in the course. Please comment on your reactions to each.

- Willing to be Disturbed (Wheatley)

- Against Common Sense: Teaching and Learning Toward Social Justice (Kumashiro)

- Teach Boldly! (Fehr \& Fehr)

- Finding Freedom in the Classroom: A Practical Introduction to Critical Theory (Hinchey)

- White Privilege: Unpacking the Invisible Knapsack (McIntosh)

- White Privilege: An Account to Spend (McIntosh)

- White People Facing Race: Uncovering the Myths that Keep Racism in Place (McIntosh)

- Oppression (Frye)

- The Color of Supremacy: Beyond the Discourse of White Privilege (Leonardo)

- Black Ants and Buddhists (Cowhey)

6. Of the texts you read, which one contributed most to your understanding of Critical Pedagogy? (This may not necessarily be your favorite, but the one you think pushed you the most to understand Critical Pedagogy.)

7. Has the Critical Pedagogy course influenced your approach to your work? If so, in what ways?

8. Has the Critical Pedagogy course influenced your personal life? If so, how?

9. A new graduate student asks you what the Critical Pedagogy course is about. What do you tell him/her?

10. Overall, please reflect on your growth in understanding of Critical Pedagogy and its relationship to your work as a practitioner scholar?

11. What recommendations do you have about improving the course for next time? 
Figure 1. Example of coding

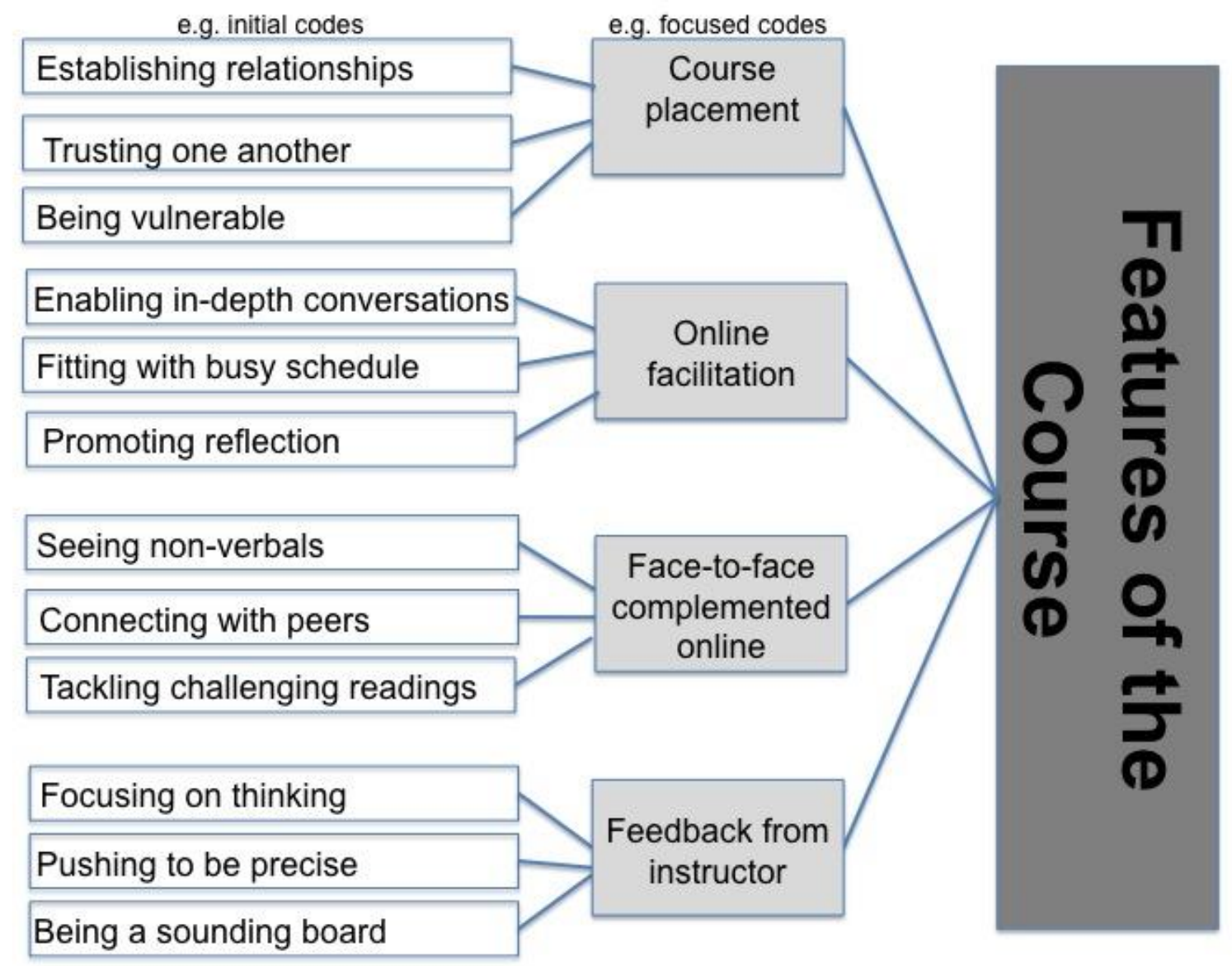

